Diabetologia 8, 377-380 (1972)

(C) by Springer-Verlag 1972

\title{
The Effect of Buformin upon Blood Glucose Level of Normal Rats and Carbohydrate Metabolism of the Isolated Rat Diaphragm
}

\author{
P. Strohfeldt, H.P. Meißner and K.F. Weinges \\ Department of Medicine, University of Saarland, Homburg/Saar, Germany
}

Received: July 6, 1972, accepted: August 24, 1972

Summary. 1. $2 \mathrm{~h}$ after a single oral dose of $25 \mathrm{mg}$ of buformin per normal rat, the blood glucose level was significantly lower when compared to the control group $(78,9+1.4 \mathrm{mg} / 100 \mathrm{ml}$ to $67.1+5.2 \mathrm{mg} / 100 \mathrm{ml}, p<0.05)$. The incubated diaphragms of these animals showed no differences with regard to glucose uptake, lactate production and glucose oxidation in comparison to the control. -2 . When treated for 7 days with identical dosages of buformin the blood glucose level of the treated rats was lowered to a greater extent $(80.5 \pm 3.7 \mathrm{mg} / 100 \mathrm{ml}$ to $51.6 \pm 5.7 \mathrm{mg} / 100 \mathrm{ml}, p<0.01$ ) and the incubated diaphragms showed a significantly increased glucose uptake, lactate production and decreased glucose oxidation. 3. As a result of these findings and supported by reports in literature it is suggested that the drug may accumulate in the skeletal muscle of normal rats. -4 . No insulin potentiating effect could be detected. -5 . With regard to previous reported results from our laboratory we suggest that biguanides may increase Cori cycle activity in the rat.

Effet de la buformine sur le taux du glucose sanguin chez le rat normal et sur le métabolisme des hydrates de carbone du diaphragme isolé du rat

Résumé. 1. Deux heures après une administration unique de $25 \mathrm{mg}$ de buformine par animal à des rats mâles normaux, le taux du glucose sanguin chez les animaux traités était significativement plus réduit par comparaison aux témoins $(78.9 \pm 1.4 \mathrm{mg} / 100 \mathrm{ml}$ à $67.1 \pm 5.2 \mathrm{mg} /$ $100 \mathrm{ml}, p<0.05$ ). Les diaphragmes incubés de ces animaux ne montraient aucune différence en ce qui concerne la captation de glucose, la production de lactate et l'oxydation de glucose par comparaison aux témoins. - 2. Après un traitement de 7 jours avec des doses identiques de buformine, le taux du glucose sanguin des rats était encore davantage réduit $(80.5 \pm 3.7 \mathrm{mg} / 100 \mathrm{ml}$ à $51.6 \pm 5.7 \mathrm{mg} /$ $100 \mathrm{ml}, p<0.01$ ) et les diaphragmes incubés montraient une captation de glucose et une production de lactate augmentées de façon significative, ainsi qu'une oxydation de glucose réduite. - 3. En tenant compte de ces résultats et avec l'appui de la littérature, on suppose que le médicament s'accumule dans les muscles du squelette des rats normaux. - 4. Aucun effet potentialisateur de l'insuline n'a été noté. - 5. En ce qui concerne les résultats déjà publiés par notre laboratoire, nous suggérons que les biguanides augmentent l'activité du cycle de Cori chez le rat.

Die Wirkung von Buformin auf den Blutglucosespiegel von normalen Ratten und den Kohlenhydrat-Stoffwechsel des isolierten Rattenzwerchfelles

Zusammenfassung. 1. Zwei Stunden nach einer einmaligen oralen Gabe von $25 \mathrm{mg}$ Buformin an normale männliche Ratten war der Blutglucosespiegel der behandelten Tiere gegenüber dem der Kontrolltiere deutlich gesenkt $(78,9 \pm 1,4 \mathrm{mg} / 100 \mathrm{ml}-67,1 \pm 5,2 \mathrm{mg} / 100 \mathrm{ml}, p<0,05)$. Dio isolierten und inkubierten $\mathrm{Z}$ werchfelle der behandelten Tiere zeigten keine Änderung der Glucoseaufnahme, Glucoseoxydation und Laktatbildung im Vergleich zu den Kontrollen. - 2. Ging der Untersuchung eine 7-tägige Behandlung der Tiere mit identischen Buformindosen voraus, so war der blutglucosesenkende Effekt größer als nach einmaliger Vorbehandlung $(80,5 \pm 3,7 \mathrm{mg} / 100 \mathrm{ml}-$ $51,6 \pm 5,7 \mathrm{mg} / 100 \mathrm{ml}, p<0,01$ ) und die Glucoseaufnahme und Laktatbildung der isolierten und inkubierten Zwerchfelle der behandelten Tiere waren wesentlich größer, die Glucoseoxydation wesentlich geringer im Vergleich zu den Kontrollen. - 3. Die Ergebnisse legen die Annahme nahe, daß Buformin im Skeletmuskel normaler Ratten akkumuliert. - 4. Ein insulinpotenzierender Effekt von Buformin konnte nicht beobachtet werden. -5 . Unter Berücksichtigung kürzlich von uns mitgeteilter Befunde aus in vivoUntersuchungen an normalen Ratten, die ergaben, daß nach mehrtägiger oraler Vorbehandlung mit $25 \mathrm{mg} \mathrm{Bu}$ formin der Einbau von Radioglucose in das Zwerchfellglykogen und der Glykogengehalt selbst erhöht waren, erscheint es möglich, daß Biguanide im Skeletmuskel normaler Ratten die Aktivität des Cori Cyclus stimulieren.

Key words: Biguanide, blood glucose level, rat diaphragm, glucose uptake, glucose oxidation, lactate production.

\section{Introduction}

The blood glucose lowering biguanides have been shown to increase glucose uptake, lactate production and glycogen breakdown of the isolated rat diaphragm with a simultaneous decrease in oxygen uptake (Williams and Tyberghein, 1957; Williams et al., 1957; Steiner and Williams, 1958; Rafaelsen, 1959; Clarke and Forbath, 1959). The concentrations of the drug required for these in vitro effects were considerably above those likely to be achieved in diabetic subjects (Tranquada, 1961; Beckmann, 1965). In support of this argument it has been questioned, whether or not the oxidation-inhibiting effect of biguanides is related to the hypoglycemic action of biguanides in vivo (Ungar, 1960). It was reported earlier from our laboratory (Strohfeldt et al., 1972) that buformin caused an increase in the glycogen content of normal rat diaphragms in vivo together with an increased incorporation of radioglucose into glycogen when the animals were pretreated over a period of $12-14$ days $(25 \mathrm{mg}$ of buformin per day per animal by stomach tube $=100 \ldots$ $125 \mathrm{mg}$ of buformin $/ \mathrm{kg}$ ). 
In the present study the effects of single, and seven days treatment with $25 \mathrm{mg}$ of buformin per animal, on the blood glucose level and glucose uptake, glucose oxidation and lactate formation of the isolated rat diaphragm are reported.

\section{Materials and Methods}

Male Sprague-Dawley rats weighing $120-150 \mathrm{~g}$ were used in all experiments. The rats were maintained under standard dietetic and environmental conditions and fasted for twelve hours before the diaphragms were removed.

The preparation of diaphragms was carried out by a modification of the method of Valance Owen and Hurlock (1954). The animals were killed by decapitation. Blood glucose level was determined in the drained blood. The abdomen was opened and the diaphragm carefully excised. It was placed immediately in icecold balanced salt solution (Krebs-Ringer-bicarbonate buffer). The diaphragm, while so immersed, was divided into four approximately equal parts, the thick posterior portion being discarded. After gentle blotting these parts were distributed in the prepared incubation flasks.

The incubation medium was $1 \mathrm{ml}$ Krebs-Ringer-bicar bonate-buffer containing $2 \mathrm{~g}$ of bovine serum albumin/ $100 \mathrm{ml}$ and glucose together with $0,1 \mu \mathrm{Ci}[1-14 \mathrm{C}]$-glucose (Spec. act. $3 \mathrm{mCi} / \mathrm{mmol})^{1}$ to make the final concentration $200 \mathrm{mg} / 100 \mathrm{ml}$. The concentration of added crystalline insulin ${ }^{2}$ to the media is shown in the tables 1 and 2.

The incubation flasks were gassed for five minutes with $95 \%$ oxygen and $5 \%$ carbon dioxide, closed and weighed. The flasks were then incubated in a water-bath at $37^{\circ} \mathrm{C}$ and shaken at a rate of 90 oscillations per minute for 120 minutes.

For the measurement of the oxidation of $[1-14 \mathrm{C}]$ glucose to $14 \mathrm{CO}_{2}$, we used the method of Renold et al. (1960): After ineubation $0.4 \mathrm{ml}$ of hyamine (Hydroxide of Hyamine 10-X, 1 Molar solution in Methanol, Packard) was injected into the suspended plastic cup and $1 \mathrm{ml}$ of $6 \% \mathrm{HClO}_{4}$ was added to the medium in each flask. Then the flasks were re-incubated in a water-bath at $37^{\circ} \mathrm{C}$ and shaken at a rate of 90 oscillations per minute for a further 30 min. The contents of each plastic cup were then transferred to a glass bottle containing $8 \mathrm{ml}$ of non-polar scintillation mixture based on toluene.

The radioactivity of $14 \mathrm{CO}_{2}$ was measured with a Packard Tricarb scintillation spectrometer. The values obtained wore expressed as counts per minute/100 mg diaphragm wet weight (ww) $/ 2 \mathrm{~h}$. After centrifugation of the medium, the final glucose uptake over the incubation period was calculated from the decrease of glucose concentration in the medium during the incubation.

Glucose was determined by the hexokinase method (Biochemica Test Combination, Boehringer Mannheim, Biochemical Department). The values were calculated in umoles glucose/100 mg diaphragm wet weight (ww)/2 h. Samples were analyzed for lactate by means of lactic dehydrogenase (Biochemica Test Combination, Boehringer Mannheim, Biochemical Department). The values were calculated in umoles lactate $100 \mathrm{mg}$ diaphragm wet weight (ww)/2 h.

The pretreated animals received $25 \mathrm{mg}$ buformin ${ }^{3}$ in a volume of $0.25 \mathrm{ml}$ per stomach tube either as a single dose

1 The Radiochemical Centre Amersham, U.K.

2 Crystalline bovine insulin, $1 \mathrm{mg}=27.0 \mathrm{u}, 0.33 \% \mathrm{zn}$, $0.49 \%$ ashes, Fa. Hoechst, Frankfurt/M., Germany.

3 Chemie Grünenthal, GmbH, Stolberg/Rheinland.
$2 \mathrm{~h}$ prior to decapitation or over a period of 7 days. The control animals received physiological saline.

The statistical estimations were performed with the Wilcoxon.-Test.

\section{Results}

Table 1 shows the measurement of glucose oxidation, glucose uptake and lactate formation of diaphragms from normal male rats after pretreatment of the animals with buformin (25 $\mathrm{mg} /$ animal) as a single dose $2 \mathrm{~h}$ prior to investigation. Glucose oxidation, glucose uptake and lactate formation revealed no significant difference between the pretreated and control animals. The blood glucose level of the control group was $69.0 \pm 3.6 \mathrm{mg} / 100 \mathrm{ml}$ and that of the pretreated animals $53.7 \pm 6.2 \mathrm{mg} / 100 \mathrm{ml}(p>0.05)$ at the time of decapitation (Table 1a).

In table 2 are shown the effects of 7 days oral treatment of normal male rats $(25 \mathrm{mg}$ buformin per day per animal) on the glucose oxidation, glucose uptake and lactate formation of the isolated diaphragms with and without crystalline insulin in the media. The diaphragms of the pretreated animals showed a significant inhibition of $14 \mathrm{CO}_{2}$ production when compared with the control animals. Without insulin in the media the change was $2.57 \pm 0.26$ to $1.74 \pm 0.15(p<0.05)$ and with insulin in the media the values were $2.65 \pm 0.19$ and $1.99 \pm 0.14 \mathrm{cpm}\left(\mathrm{x} 10^{3}\right) \quad 14 \mathrm{CO}_{2} / 100 \mathrm{mg} \mathrm{ww} / 2 \mathrm{~h}$ $(p<0.05)$. The glucose uptake of the isolated diaphragms of the pretreated animals was significantly higher than that of the controls when incubated without insulin in the media $(4.03 \pm 0.32 / 3.17 \pm 0.20$ umoles glucose $/ 100 \mathrm{mg}$ ww/2 h $(p<0.05)$. With insulin in the media there was a similar rise in glucose uptake but it was not statistically significant. The lactate formation increased from $5.16 \pm 0.32$ to $7.23 \pm$ $0.33 \mu$ moles lactate $/ 100 \mathrm{mg}$ ww $/ 2 \mathrm{~h}(p<0.05)$ without insulin and from $5.74 \pm 0.30$ to $7.23 \pm 0.22 \mu$ moles lactate $/ 100 \mathrm{mg} \mathrm{ww} / 2 \mathrm{~h}(p<0.05)$ with insulin in the test system.

At the time of decapitation the blood glucose level of the pretreated group amounted to $51.6 \pm 5.7 \mathrm{mg} /$ $100 \mathrm{ml}$ in comparison with $80.5 \pm 3.7 \mathrm{mg} / 100 \mathrm{ml}$ of the control $(p<0.01$, table $2 \mathrm{a})$.

\section{Discussion}

We consider the incubated rat diaphragm preparation adequate for our investigations. Rookledge (1971) compared several parameters (water content, sorbitol space, rate of lactate production, the concentrations of tissue glucose, pyruvate, lactate, ATP and AMP) in both the perfused and non perfused incubated preparations of diaphragm and no significant differences were found. Under our conditions we found a significant effect on glucose uptake with insulin concentrations of $10^{-3} \mathrm{U} / \mathrm{ml}$. With $5 \times 10^{-3} \mathrm{U} / \mathrm{ml}$ no increasing effect was observed. 
After a single oral dose of $\mathbf{2 5} \mathrm{mg}$ of buformin per animal $2 \mathrm{~h}$ before investigation the blood glucose level was $53.7 \pm 6.2 \mathrm{mg} / 100 \mathrm{ml}$ in comparison to 69.0 士 $3.6 \mathrm{mg} / 100 \mathrm{ml}$ of the control group $(p>0.05)$. In order to elucidate the significance of this observation, the treatment was repeated with a greater number of animals $(n=20)$. On this occasion the difference in blood glucose levels $2 \mathrm{~h}$ after the buformin administration became significant in comparison to the control cose oxidation, in comparison to the control diaphragms.

With submaximal concentrations of insulin in the medium no potentiating effect could be detected after the pretreatment with buformin.

We conclude from the results of experiments with single and 7 days pretreatment with buformin, that either the blood glucose lowering effect of the biguanides is not caused by the observed alterations in the

Table 1. Rates of [1-14C]-glucose oxidation, glucose uptale and lactate formation in normal male rat diaphragms incubated in vitro after a single dose of buformin by oral intubation $(25 \mathrm{mg}) 2 \mathrm{~h}$ before investigation. Numbers of animals and observations are given in brackets. Means $\pm S_{\bar{x}}$

\begin{tabular}{|c|c|c|c|c|c|c|c|c|}
\hline \multicolumn{3}{|c|}{$\begin{array}{l}\text { Medium concentrations insulin } \\
(\mu \mathrm{U} / \mathrm{ml})\end{array}$} & \multicolumn{2}{|c|}{$\begin{array}{l}\text { umoles glucose uptake/ } \\
100 \mathrm{mg} \mathrm{ww} / 2 \mathrm{~h}\end{array}$} & \multicolumn{2}{|c|}{$\begin{array}{l}\text { Rate cpm }\left(\times 10^{3}\right){ }^{14} \mathrm{CO}_{2} / \\
100 \mathrm{mg} \text { wet weight } / 2 \mathrm{~h}\end{array}$} & \multicolumn{2}{|c|}{$\begin{array}{l}\text { umoles lactate formation/ } \\
100 \mathrm{mg} w \mathrm{ww} / 2 \mathrm{~h}\end{array}$} \\
\hline Control & 0 & (4) & $4.45 \pm 0.24$ & (6) & $2.17+0.33$ & (6) & $6.36+0.65$ & (6) \\
\hline Pretreated animals & 0 & (4) & $3.99+0.53$ & (6) & $1.72+0.08$ & (6) & $6.86+0.78$ & (6) \\
\hline Control & 500 & (4) & $5.15+0.38$ & (10) & $2.46+0.19$ & (10) & $6.46+0.63$ & (10) \\
\hline Pretreated animals & 500 & (4) & $5.03 \pm 0.37$ & (10) & $2.29 \pm 0.19^{\mathrm{a}}$ & (10) & $6.44 \pm 0.69$ & (10) \\
\hline
\end{tabular}

a Significantly different from the group of pretreated animals without insulin in the medium $(p>0.05)$.

Table 1 a: Blood glucose level at the time of decapitation

$\begin{array}{lll}\text { Animals } & & \text { Blood glucose }(\mathrm{mg} / 100 \mathrm{ml}) \\ \text { Control } & (4) & 69.0 \pm 3.6 \\ \text { Treated animals } & (4) & 53.7 \pm 6.2^{\mathrm{a}}\end{array}$

a Not significantly different from control $(p>0.05)$.

Table 2. Rates of [1-14C]-glucose oxidation, glucose uptake and lactate formation in normal male rat diaphragms incubated in vitro after 7 days treatment with $25 \mathrm{mg}$ buformin by oral intubation. Last dose $2 \mathrm{~h}$ before investigation. Numbers of animals and observations are given in brackets. Means $\pm S_{\bar{X}}$

\begin{tabular}{|c|c|c|c|c|c|c|c|c|}
\hline \multicolumn{3}{|c|}{$\begin{array}{l}\text { Medium concentrations insulin } \\
(\mu \mathrm{U} / \mathrm{ml})\end{array}$} & \multicolumn{2}{|c|}{$\begin{array}{l}\text { uraoles glucose uptake/ } \\
100 \mathrm{mg} \mathrm{ww} / 2 \mathrm{~h}\end{array}$} & \multicolumn{2}{|c|}{$\begin{array}{l}\text { Rate cpm }\left(\times 10^{3}\right){ }^{14} \mathrm{CO}_{2} / \\
100 \mathrm{mg} \text { wet weight } / 2 \mathrm{~h}\end{array}$} & \multicolumn{2}{|c|}{$\begin{array}{l}\text { umoles lactate formation, } \\
100 \mathrm{mg} \mathrm{ww} / 2 \mathrm{~h}\end{array}$} \\
\hline $\begin{array}{l}\text { Control } \\
\text { Pretreated animals } \\
\text { Control } \\
\text { Pretreated animals }\end{array}$ & $\begin{array}{r}0 \\
0 \\
500 \\
500\end{array}$ & $\begin{array}{l}(6) \\
(6) \\
(6) \\
(6)\end{array}$ & $\begin{array}{l}3.17 \pm 0.20 \\
4.03 \pm 0.32^{a} \\
3.67 \pm 0.28 \\
4.38 \pm 0.28\end{array}$ & $\begin{array}{l}(12) \\
(12) \\
(12) \\
(12)\end{array}$ & $\begin{array}{l}2.57 \pm 0.26 \\
1.74 \pm 0.15^{a} \\
2.65 \pm 0.19 \\
1.99 \pm 0.14 a\end{array}$ & $\begin{array}{l}(12) \\
(12) \\
(12) \\
(12)\end{array}$ & $\begin{array}{l}5.16 \pm 0.32 \\
7.23 \pm 0.33^{\mathrm{a}} \\
5.74 \pm 0.30 \\
7.23 \pm 0.22^{\mathrm{a}}\end{array}$ & $\begin{array}{l}(12) \\
(12) \\
(12) \\
(12)\end{array}$ \\
\hline
\end{tabular}

a Significantly different from control $(p<0.05)$.

Table 2a. Blood glucose level at the time of decapitation

$\begin{array}{lll}\text { Animals } & \text { Blood glucose }(\mathrm{mg} / 100 \mathrm{ml}) \\ \text { Control } & (6) & 80.5 \pm 3.7 \\ \text { Treated animals } & (6) & 51.6 \pm 5.7^{\mathrm{a}}\end{array}$

a Significantly different from control $(p<0.01)$.

animals $(78.9 \pm 1.4 \mathrm{mg} / 100 \mathrm{ml}$ to $67.1+5.2 \mathrm{mg} / 100 \mathrm{ml}$ $p<0.05)$. The isolated diaphragms showed no difference between treated and untreated animals in regard. to glucose uptake, lactate production and glucose oxidation.

After 7 days oral treatment with $25 \mathrm{mg}$ of buformin the blood glucose level of the treated group differed markedly from that of the untreated animals $2 \mathrm{~h}$ after the last dosage $(80.5 \pm 3.7 \mathrm{mg} / 100 \mathrm{ml}$ to $51.6 \pm 5.7 \mathrm{mg} /$ $100 \mathrm{ml}, p<0.01)$. The isolated and incubated diaphragms of the treated animals showed an increased glucose uptake, lactate formation and decreased glu- muscle metabolism. Alternatively the low sensitivity of the test system may explain the negative results obtained with the diaphragms from the animals pretreated with a single dose. Significant effects on muscle metabolism were found after a 7 days pretreatment, together with a more pronounced lowering of the blood glucose level. This could be achieved if one were to assume a cumulative effect of the drug on muscle metabolism. The following results give support to this point of view: $24 \mathrm{~h}$ after oral administration of $50 \mathrm{mg} / \mathrm{kg}$ of buformin-[14C] to normal rats Beckmann (1965) found $0.9 \mu \mathrm{g} / \mathrm{g}$ wet weight of buformin in the 
skeletal muscle, the highest concentration when compared with other organs. Hall et al. (1968) also detected considerable amounts of labeled phenformin in normal rat muscles $24 \mathrm{~h}$ after parenteral administration (100 $\mathrm{mg} / \mathrm{kg})$.

With regard to our previously published results (Strohfeldt et al., 1972) with in vivo administration of radioactive glucose; the incorporation into glycogen and the glycogen content of the diaphragms of normal rats following several days pretreatment with buformin (25 mg per day animal orally) showed an increased incorporation of radioglucose together with an increased glycogen content of the diaphragms $2 \mathrm{~h}$ after the last dose of the drug. Our in vitro observations suggest that biguanides may increase Cori cycle activity in normal rats. The findings of several investigators give support to this assumption (Searle et al., 1966; El Defrawy a. Buckley, 1971; Davies et al., 1971).

\section{References}

1. Beckmann, R.: Resorption, Verteilung im Gewebe und Ausscheidung von 1-Butyl-biguanid 14C-hydrochlorid. Arzneimittel-Forsch. (Drug Res.) 15, 761 -764 (1965).

2. Clarke, D.W., Forbath, N.: Some studies on the mode of action of DBI. Metabolism 8, 553-556 (1959).

3. Davies, W.H., Martin, L.E., Mills, J.G., Vardey, C. J.: Influence of biguanides on glucose turnover in the rat and dog. 7 th Ann. Meeting of the Europ. Ass. for the Study of Diab., Southampton, Sept. 1971, abstract 45 .

4. EI Defrawy, S., Buckley, J.P.: Metabolic effects of phenformin at simulated high altitude. J. Pharmacol. exp. Ther. 177, 276-279 (1971).

5. Hall, H., Ramachander, G., Glassman, J.M.: Tissue distribution and excretion of pheniormin in normal and diabetic animals. Ann. N. Y. Acad. Sei. 148, 601611 (1968).
6. Rafaelsen, O.J.: Action of oral antidiabetic drugs on carbohydrate motabolism of isolated rat diaphragm. Motabolism 8, 195-204 (1959).

7. Renold, A. E., Martin, D.B., Stoinke, J., Dagenais, V. M., Nickerson, R.J., Sheps, M.C.: Measurement of small quantities of insulin-like activity using rat adipose tissue. I. A. proposed procedure. J. clin. Invest. 39, 1487-1498 (1960).

8. Rookledge, K.A.: Comparison of some metabolic parameters in the perfused and the incubated rat diaphragm muscle with diaphragm muscle in vivo. Biochem. J. 125, $93-96$ (1971).

9. Searle, G.L., Sohilling, S., Porte, D., Barbaccia, J., De Grazia, J., Cavalieri, R.R. : Body glucose kinetics in nondiabetic human subjects after phenethylbiguanide. Diabetes 15, 173-178 (1966).

10. Steiner, D.F., Williams, R.H. : Respiratory inhibition and hypoglycemia by biguanides and decamethylenediguanidine. Biochim. biophys. Acta 30, 329-340 (1958).

11. Strohfeldt, P., Ehrhardt, M., Kettl, H., Weinges, K. F.: Experimental studies on the glycogen content and the incorporation of radioglucose into the glycogen of the diaphragm of rats after initial and short term administration of buformin. Diabetologia $8,37-40$ (1972).

12. Tranquada, R.E.: The mechanism of action of phenethylbiguanide. $4^{\mathrm{e}}$ congr. féd. int. du diabète. Genève, Editions Médecine et Hygiène, 1961, pp. 716-717.

13. Ungar, G., Psychoyos, S., Hall, H.A.: Action of phenethylbiguanide, a hypoglycemic agent, on tricarboxylic acid cycle. Metabolism 9, 36-51 (1960).

14. Vallance-Owen, J., Hurlock, B. : Estimation of plasma insulin by the rat diaphragm method. Lancet 1954 I, $68-70$.

15. Williams, R.H., Tyberghein, J.M.: Metabolic effects of phenylethylbiguanide, a new hypoglycemic compound. Proc. Soc. exp. Biol. 96, 29-32 (1957).

16. Williams, R.H., Tyberghein, J.M., Hyde, P.M., Nielsen, R.L.: Studies related to the hypoglycemic action of phenethylbiguanide. Metabolism 6, 311-319 (1957).

Prof. Dr. K. F. Weinges

Med. Universitätsklinik u. Poliklinik

D-665 Homburg/Saar

Federal Republic of Germany 